\title{
From Social Performance to Expressing the 'True Self': The Change in the Communicational Assumptions in Polish Letter-Writing Manuals from the Eighteenth and the Early Nineteenth Centuries in the Context of the Emergence of Modern Sincerity in the West
}

\author{
Agata Sikora
}

Independent Researcher

\section{ABSTRACT}

While the traditional model of verbal expression was founded on the premise that individuals should skilfully use conventions in order to achieve their goals, the modern approach, based on sincerity, assumes that people should problematise the truth about their own selves, and their utterances should be interpreted in relation to that truth. The article traces the emergence of the new concept of communication by analysing Jean-Jacques Rousseau's Confessions and Julie, or the New Heloise, and Polish letter-writing manuals from the eighteenth and early nineteenth centuries, putting emphasis on the premises of the new attitude (emergence of modern subjectivity, interpreting communication in referential rather than performative terms) and the wider socio-cultural context (emancipation of middle classes, transition from orality to literacy). ${ }^{1}$

Keywords: modernity, sincerity, Polish culture, letter-writing manuals

\section{ABSTRAKT PO POLSKU}

Podczas gdy tradycyjna koncepcja komunikacji zakładała, że osoba powinna używać konwencjonalnych zwrotów przewidzianych dla danej sytuacji społecznej, podejście oparte na szczerości wymaga, by jednostka problematyzowała prawdę 
o swoim ' ja', a jej wypowiedzi były interpretowane w odniesieniu do tej prawdy. By zrekonstruować wyłanianie się nowego podejścia w XVIII wieku, zanalizuję Wyznania i Nowa Heloize Jana Jakuba Rousseau oraz polskie listowniki, kładąc nacisk na założenia nowego sposobu komunikowania się (nowoczesna subiektywność, myślenie o komunikacji w kategoriach referencjalnych, a nie performatywnych) oraz szerszy kontekst historyczno-kulturowy (emancypacja mieszczaństwa, przejście od oralności do piśmienności).

Stowa kluczowe: nowoczesność, szczerość, kultura polska, listowniki

In 1832 Juliusz Słowacki, one of the three 'Romantic Bards', the great poets who deeply influenced Polish culture, declared in a letter to his mother: 'You see how sincerely I write this journal, I even write down my stupid fantasies. Let these letters at least, Dear Mother, show you how much I love you, how much I would like to contribute to your happiness'.2 According to Słowacki's declarations, constantly repeated in this correspondence, sincerity is final proof of emotional engagement. Letters to one's nearest are compared to a personal journal: they should reveal the subjective inner truth of the writer.

Although these assumptions may seem obvious from a contemporary perspective, the idea that people should be absolutely open in interpersonal communication was relatively new in nineteenth-century Europe. Its novelty is even more striking in the 'local' context: how did the attitude towards communication change to make possible the transition from sarmatism, the deeply conservative culture of Polish nobles prevailing in the middle of the eighteenth century, to flourishing Polish Romanticism in the 1830s? How may this change be interpreted in the framework of Western modernity, without losing sight of the particularity of socio-economic circumstances in the Polish-Lithuanian Commonwealth? In an attempt to answer these questions, I will sketch the emergence of the new attitude towards expression in the West, treating Jean-Jacques Rousseau's thought as a distinctive example of its most important features. In the next step I will analyse Polish material, showing the differences and similarities of the local shift to a modern communicational model.

\section{THE MODERN MIDDLE-CLASS VIRTUE}

'Sincerity'-like 'nation'-is one of those treacherous concepts that seem 'natural' and 'ancient' while in fact they have modern roots. Contrary to our intuitions, it is not a fundamental Judeo-Christian value. The ancient 
Greeks approved of lying and deception as pragmatic tools used for dealing with people. ${ }^{3}$ The ninth commandment is 'You shall not bear false witness against your neighbour', which does not actually mandate telling the truth, but rather forbids the use of lies against somebody. The medieval concept of concordia did not assume that people should express their 'true' feelings, but rather that they should strive to achieve inner states which were ascribed to the given situation. ${ }^{4}$

The notion of sincerity emerged quite late, in the sixteenth century, originating mainly from protestant circles. At first it was a religious virtue associated with purity and plainness, based on the assumption that dedicated believers could open their souls before God without fear. It was treated as a sign of being one of the saved-which means that other people were thought to be its witnesses rather than its addressees. ${ }^{5}$ This attitude changed in eighteenth-century sentimentalism, when sincerity came to be secularised and became a proof of sensibility. It started to be associated with relationships with people, not with God, and the tension between expressing 'true feelings' and social norms emerged. ${ }^{6}$

As Norbert Elias and Colin Campbell showed in German and British contexts respectively, the focus on sensibility should be seen in the light of the middle-class emancipation process. ${ }^{7}$ Linking compassion, naturalness and culture with moral goodness enabled people lacking noble status to differentiate themselves from 'crude' and 'unrefined' peasantry and workers, while at the same time claiming moral superiority over 'artificial' and 'superficial' aristocracy. The main characters of bestselling eighteenth century novels-Pamela, or, Virtue Rewarded (1740) by Samuel Richardson in Great Britain, Julie, or the New Heloise (1761) by Jean-Jacques Rousseau in France or The Sorrows of Young Werther (1774) by Johann Wolfgang Goethe in Germany-defied unfairness of the social order by asserting their morality based on inner feelings and displaying it in speech, writing and behaviour. Reading such literature could itself have been a moral test: Lady Louisa Stewart mentioned for example that when reading The Man of Feeling (1771) by Henry Mackenzie as 'a girl of fourteen not yet versed in sentiment', she had had 'a secret dread [she] should not cry enough to gain the credit of proper sensibility'.

Numerous scholars show that the ideal of sincerity formulated by sentimentalists played an important role in shaping the modern order. William Reddy interprets the Reign of Terror during the French Revolution as a logical consequence of the new emotional regime. Arthur Melzer points out that sincerity is closely linked with democracy, where, in contrast to aristocratic societies, people can express their egoistic interests more freely. Richard Sennett indicates that rejection of using conventional signs in favour of expressing personality led to deterioration of the public life. 
Charles Taylor traces the way in which the idea of 'true' 'deep' selfhood has become a cornerstone of secularised spiritual life. Adam Seligman and his collaborators show that thinking in terms of sincerity rather than ritual is interwoven in Western modernity and biases our own thinking. ${ }^{9}$

To avoid the pitfalls of this bias, it is important to understand the transformation of communicational assumptions in the eighteenth century. As scholars including Philippe Lejeune, Arthur Melzer, Charles Taylor, Charles Guignon, Bronisław Baczko and Michał Warchala consider Rousseau's thought to be a vital articulation of the change in the attitude towards expression and the self, ${ }^{10}$ I will analyse Confessions and Julie, or the New Heloise: the works in which the author not only consciously reflects on the way people communicate, but also formulates one of the most influential projects of the new approach.

\section{TWO CONCEPTS OF COMMUNICATION}

The pre-modern model of verbal expression, rooted in orality, was based on an assumption that people should communicate with each other using ready-made formulas which had to be learned and then applied in welldefined social situations. The aim of the speaker or the writer was not to describe any phenomenon in its particularity, but rather to find analogies and skilfully use established phrases in order to influence receivers. ${ }^{11}$ Such communication could be compared to a game: there were clearly established rules of speaking and writing (rules of the game), while utterances were like ready-made tokens which had conventional meanings and could be used as responses to interlocutors' moves. The speakers and the writers (players) did not 'express' themselves but performed a social action (a play). In consequence, their utterances should have been assessed in terms of appropriateness or effectiveness rather than the true-false opposition. Such 'logic' of communication provided a framework for numerous language practices: from polite salon conversation, through the art of rhetoric, to composing poetry according to classical rules. ${ }^{12}$ Basing on Adam Seligman's and his collaborators' understanding of ritual as a performative act performed within the as if... mode, ${ }^{13}$ I propose to call it a 'ritual' concept of communication.

Rousseau's writings are directed against such an attitude. As SaintPreux, the main character of Julie...writes from his exile in Paris:

I do not understand the country's language, and no one here understands mine.

Not that I am not showered with greetings, civilities, kindnesses, and not that I do not attract a thousand officious marks of attention. But it is precisely 
to this that I object. How is one supposed to be all of a sudden the friend of someone one has never met? The honest interest of mankind, the simple and touching outpouring of a candid soul, speak a language very different from the false demonstrations of politeness... ${ }^{14}$

Saint-Preux perceives Parisians as deceitful because he assesses the ritual communication of the great world in terms of the true-false opposition, while they themselves treat it as an exchange of conventional tokens. Conversely, the correspondence between Saint-Preux, his lover Julia and their friend Claire is provided as an example of sincere expression and was interpreted as such by numerous contemporary readers. In the second, dialogic preface to Julie... the interlocutor called R. observes that expression of 'true' feelings is very different from 'the fancy jargon of the passions' ${ }^{\prime 5}$ learnt in French salons and depicted in novels:

\begin{abstract}
A letter from a truly passionate Lover, will be desultory, diffuse, full of verbose, disconnected, repetitious passages. His heart, filled with an overflowing sentiment, ever repeats the same thing, and is never done... there is nothing in it to admire, or to be struck by. The strength of the sentiment may not strike us, but its truth affects us, and that is how one heart can speak to another. ${ }^{16}$
\end{abstract}

To put it in other words: R. suggests that expression of true feeling may be mundane and boring.

Similarly, in Confessions Rousseau states that his story, which might be inappropriate, tedious, difficult to read, is worth being told in detail as it shows him 'in all the truth of nature'. ${ }^{17}$ He challenges the traditional approach to composing a literary piece, founded on obeying the rules of decorum and emulating established patterns, claiming that his right to self-expression is above his respect for the audience. This marks a vital transition: addressees are not to be pleased or seduced by the author's dexterity, but they should be captivated by the truth and power of the feeling. Therefore, communication is to be understood in terms of referentiality (an utterance has to refer to the inner state of the writer or the speaker and has to be assessed in relation to truth) instead of social performativity (an utterance has to be used effectively as a token in a social game).

In consequence, sincerity is the central moral value in Confessions. In contrast to the religious protestant practices, Rousseau addresses his sincerity to other people, the Supreme Judge in his preamble serving only as its guarantor. While the traditional concept was founded on passive transparency of the uncorrupted heart, Rousseau consciously problematises the relationship between his inner self and the text. ${ }^{18}$ 
Hence, he frequently suspends the narration to make meta-reflections on his method and dispel the reader's potential doubts. For example:

If I were to take it upon myself to draw conclusions from all this and to say to my reader, 'Such is my character', he might think, if not I deceiving him, then at least that I am deceiving myself. But in setting out for him, with total simplicity, everything that has happened to me, everything I have done, everything I have thought, everything I have felt, I cannot, except by design, lead him astray; and even if this were my design, I would not easily achieve it by this means. It is for the reader to assemble all these elements and to determine the being that they constitute; the result must be his own work, so that if he is mistaken, all the error is on his side. [...] It is not for me to judge the importance of the facts, I must simply relate them all and leave to him the task of choosing among them. ${ }^{19}$

Not only does Rousseau aim to be absolutely sincere, he also invents a method preventing himself from unintended deception. He asserts that he did not present his opinions, but only gave an objective and precise account of his inner states. This indicates that he believes in the possibility of 'transparent description' of the self, based on 'pure facts'. At the same time, he is strongly convinced that there is only one proper 'sense' of his deeds and feelings.

The discussed change within the concept of communication may be interpreted in the light of orality and literacy theory, formulated by Walter Jackson Ong, Eric Havelock and Jack Goody, and revised by David Olson. Ong stressed that till the eighteenth century verbal art in the West was associated with rhetoric, a discipline based on skilful use of ready-made formulas (a kind of token with socially defined meaning) to persuade an addressee or defeat a rival - not to establish the truth..$^{20}$ In parallel, as Olson notes, a new discourse had been developing since the reformation: modern prose, which should be written and read as an expression of its author's intentions, not as a sign referring to other hidden or conventional meaning (like in medieval interpretation of the Bible or rhetorical usage of topoi). The paradigmatic example of the new approach is writings of empiricists, in which descriptions of experiments were clearly differentiated from their interpretations to enable the reader to critically follow the path of logical reasoning, basing on the same 'objective' facts. ${ }^{21}$

Rousseau applies a very similar strategy in his Confessions: like the empiricists, he believes that it is possible to separate facts from their interpretations (even if these 'facts' cannot be verified by other people). He does not seek forgiveness (like in Christian sacrament), but rather asserts his 'objective' innocence following the 'scientific' procedures of his time. If the reader is honest, he cannot see things differently: there is only one truth and one way of proper reasoning. 
Therefore, the analysis of Confessions shows that the modern idea of the self and subjectivity was closely interlinked with a new approach toward communication and the transition from orality to literacy. Focusing on the latter will enable me to describe the process of emergence of modern sincerity in eighteenth century Polish culture, in which the middle class and its genres and virtues were very weak.

\section{SARMATIAN RHETORICAL COMPENDIA}

In the seventeenth century, while modern states were emerging in the West as a result of the processes of centralisation, bureaucratisation and emancipation of the middle classes, in the Polish-Lithuanian Commonwealth the political system of the nobles' democracy was gradually deteriorating. The state was ruined by wars with Turkey, Sweden, Russia and the Cossack uprising; central power was in decay. The nobility (szlachta) had political rights, including the right of a single individual to block a session of the Parliament (Sejm), but had lost its political power. Polish politics was shaped by foreign states (Russian Empire, Kingdom of Prussia and Habsburg Monarchy) and the local aristocracy (magnats), who easily bribed impoverished nobles to paralyse the work of the Sejm. This situation resulted in the state turning into a 'federation of neighbourhoods' ${ }^{22}$ governed by magnats who derived huge incomes from latifundia-type estates, exporting grain to the West. In consequence the development of cities and emancipation of the middle classes were almost totally suppressed, while the economy was based on extensive agriculture and the labour of personally-dependent serfs. The dominant noble culture called sarmatism was patriarchal, rooted in locality and conservative.

Nevertheless, the myth of having inherited the legacy of the Roman Republic was a cornerstone of the Polish nobles' identity and democratic practices were still officially maintained: this is why the art of rhetoric played a vital role in the nobles' culture. Rhetorical patterns, formulas, pompous style, the tendency to hyperbolic comparisons and mixing Polish with Latin (makaronizm) shaped numerous contemporary genres. In general, sarmatism to a large extent preserved an approach characteristic of oral cultures: it focused on interaction rather than self-analysis, on relationships rather than the self, and did not differentiate between the public and the private spheres. ${ }^{23}$

Hence, using the term 'letter-writing manual' in reference to Polish publications on letter-writing from the end of the seventeenth and the first half of the eighteenth century seems problematic. ${ }^{24}$ In fact Wymowny polityk w listach różnych z responsami, w dyskursach politycznych, w weselnych i pogrzebowych mowach etc. etc. [An Eloquent Politician in Diverse 
Letters and Replies, in Political Discourses, in Wedding and Funeral Speeches etc. etc.] (1694) by Jakub Boczyłowic, Fama polska publiczne stany $i$ mtódź szlachetna informujaca [The Fame Informing the Public and the Noble Youth] by Kazimierz Wieruszewski (1720), Polak sensat w liście, w komplemencie polityk, humanista $w$ dyskursie, w mowach statysta [The Pole an Erudite in Letters, a Politician in Compliments, a Humanist in Discourse, a Statesman in Speeches] by Wojciech Bystrzonowski (1730) or Swada polska i tacińska... ${ }^{25}$ [Polish and Latin Fluency...] by Jan Ostrowski-Danejkowicz (1745) are rhetorical compendia. The editors do not present any theory, but deliver models and examples of letters and speeches composed according to the rules of rhetoric. ${ }^{26}$ There is no difference between written and oral style: the same formulas rooted in traditional topoi are to be used in speaking and in writing. Their choice is determined by the social action which the speaker or the writer wants to perform (greeting, inviting, thanking etc.), the place occupied by the participants of communication in the social hierarchy, and the subject matter. These variables are detailed in the title of a given model (for instance: 'A letter in which a father invites a senator to his daughter's wedding'). Models do not describe a situation in its particularity, but provide a set of ready-made expressions that are appropriate in a given context. Here is a representative model taken from Boczyłowic's collection:

A letter of a husband inviting [mourners] to his wife's funeral.

Divine Vota [vows] have bound us, fata [fate] has sundered us, and it would have been better not to have known a friend, than to be separated from them. But all of us, I see, come under fatis [destiny]: metam properamus ad unam [we hasten to one common goal]. So I too ad hanc metam [to this aim] wanting to erect colossum [a monument] aeternitatis [eternal] for my wife in her mortal coffin, and to give the final friendly benevolence, I invite WMM Pana $^{27}$ pro die [on day] N., for which I will be indebted to you, I remain WMM Pan's [servant]. ${ }^{28}$

The widower does not express his inner states in the first person (for instance 'I am in despair').$^{29}$ Instead of exploring his subjectivity, he presents a universal reflection on the human condition using rhetorical topoi. Grief is expressed by a sentence referring to a general truth ("it would have been better not to have known the friend, than to be separated'), affection-by performing an act of 'the final friendly benevolence', which refers to conducting the funeral ceremony in the proper way. The reply that follows is rooted in topoi of Christian consolation: it reminds the mourner of the dogmatic truths (immortality of the soul) and advises restraining despair. It refers to the individual bond of the couple ("[the 
eternal soul] has inscribed in its heart the immortal presence of its friend ${ }^{30}$ ), but without individualising it: the same sentence could be used for any marriage. Such models imply that neither the widower nor the comforter has to focus on this particular interpersonal relation in all its complexity.

Moreover, in the discussed rhetorical compendia the choice of formula depends on social status instead of the emotional distance between writer, addressee and deceased. In Polak sensat... Bystrzonowski provides seven models of invitations to a funeral, in which emotional expression is regulated by rank in the patriarchal order. For example, in the model entitled 'A son invites a senator to his father's funeral', the writer underlines his own inferiority and makes a humble request. Deep grief is ascribed to the son, while the senator is depicted in quasi-religious terms: he is compared to the sun and his presence in itself has the power of consolation. The highly-ranked person is not expected to experience anything, but to influence the emotions of others. The son describes his own pain with elaborate comparisons, underlining the social consequences of the death-his orphanhood and the need for protection. In another situation-'A son invites a neighbour to his father's funeral' ${ }^{31}$ - the deceased and the addressee are equals while the son is inferior to his father and in consequence to the neighbour (but he is about to take his father's place in the social hierarchy). In such circumstances, the son pays his respects by starting the letter with a description of the addressee's grief and referring to neighbourly friendship seen not as an intimate bond, but a social relationship of equals. Then he describes his own pain using conventional formulas referring to the inner state of a son who has lost his father. That he should be 'on the brink of the madness' might be seen as a social rule rather than a question of the subjective feelings of a given person.

These examples show that within the ritual concept of communication, an individual has to use prescribed formulas according to a wellknown script. Such an approach does not incline people to analyse their subjectivity, but rather provides an elastic framework that enables them to inscribe their experience in the wider social and metaphysical context. As Seligman and his collaborators underline, the ritual approach gives people more freedom than sincerity does: it obliges them to perform prescribed actions, but does not require them to feel particular 'true' emotions. If a widower is deeply immersed in grief, the rhetorical pattern of exordium, laudatio, comploratio, consolatio, exhortatio helps him to deal with his experience; if his emotions are ambiguous, the ritual frame leaves space for ambivalence. 
If the term szczerośc [sincerity] is mentioned within these publications, it is embedded in a semantic field associating it with purity. The Polish words szczery and szczerość were treated from the sixteenth to the eighteenth century as equivalents of the Latin sincere and sinceritas and they referred to being right, clean, pure, incorrupt, whole, virtuous and simple. In relation to people, szczerość evoked having a pure mind or heart that was not corrupted by dissimulation. The virtue, it might be said, was founded on passive transparency: neither inner feelings nor the act of communication itself had to be problematised.

Such a notion of sincerity underpins Przydatek do uwag zupetnemu stanowiących się szczęściu stużących... [A Supplement to Comments Serving Full Happiness...] (1747) by Aleksander Paweł Zatorski. ${ }^{32}$ This original book is a supplement to a savoir-vivre manual composed as an epistolary novel depicting the romance of Chloryda and Rożyn. While the compendia discussed above were addressed to nobles who had to internalise certain scripts of behaviour regulated by the social hierarchy, Zatorski aims to foster French patterns of courtly love and make the Polish language capable of expressing delicate feelings. Nevertheless, even if his characters emphasise their sincerity and speak about their hearts instead of using rhetorical formulas, they do not problematise their subjectivity and the act of communication as Rousseau does-they do not differentiate between the inner sphere (true feelings) and the outer sphere (behaviours and social world). For them sincerity is not a task to be accomplished: it is simply transparency.

This observation corresponds with Hanna Dziechcińska's research showing that even in personal writing such as journal diaries sarmatians of the first half of the century did not express their subjective perspective. ${ }^{33}$ Unsurprisingly, the break with rhetorical tradition was closely linked with the adoption of cultural patterns from the West.

\section{SENTIMENTAL LETTER-WRITING THEORY}

Zatorski's book should be viewed in the context of initiatives and movements aiming to modernise and westernise Polish culture in the second half of the eighteenth century. The most important circle was centred around king Stanisław August Poniatowski (elected in 1764), who tried to foster Enlightenment ideas, French customs and classicism. The reformers fought against sarmatism, depicting it as obscure, primitive and backward. One of their most important postulates was related to communication: they wanted to purify the Polish language, ridding it of Latin influences, and overcome the pompous rhetorical style. In the 'Monitor', the Polish journal emulating 'The Spectator', they attempted to foster journalist discourse founded on empiricism and rational reasoning'modern prose', to use Olson's term. 
These tensions are reflected in letter-writing theory as well. In 1755 Franciszek Bohomolec, a famous reformer of education and a collaborator of the 'Monitor', published Zabawki oratorskie... [Oratory Trifles...], a compendium addressed to noble youth, which was free from mixing Polish and Latin and contained a theory of letter-writing set out in a clear, rational way. Nevertheless, the real revolution in the attitude towards expression took place two decades later, when Stanisław Szymański published Wzory biletów, listów $i$ memoriatów w różnych materiach... [Examples of Cards, Letters and Petitions on Various Subjects...] (1784), the first sentimental letter-writing manual in Polish.

This period saw the adoption of sentimentalism in Polish culture. In 1783, after the political split between Prince Adam Kazimierz Czartoryski and King Stanisław August Poniatowski, Adam's wife, Princess Izabela Czartoryska née Fleming, created Puławy, a new centre of intellectual life promoting sentimentalism to compete with the classicism of the royal court. The Princess supported poets, organised courtly performances, set up splendid gardens and then, after the partition of the state (1795), gathered a collection of relics related to Polish culture, establishing the first Polish museum. Her affection for her children and engagement in maternity was seen as a novelty and emulated by others. Letters exchanged within her circle are an example of the new emotionality, displaying sensibility and focusing on feelings. ${ }^{34}$

Nevertheless, the whole cultural project of Puławy was rather conservative: developed as a part of court life, implicitly patriarchal and idealising the past. Unlike in Western Europe, in the eighteenth-century PolishLithuanian Commonwealth the new emotional style was internalised rather by the aristocracy, who belonged to the cosmopolitan European elite, than by the middle classes. This might explain to some extent why Rousseau's works were not translated (in Puławy they were read in French) and why in the eighteenth century there were few translations of Western sentimental novels and almost no original attempts in the genre (the most famous one, Malwina, czyli domyślność serca [Malwina or the Perspicacity of the Heart], was written by Izabela's daughter Maria Wirtemberska and published only in 1816).

The middle-class approach, on the other hand, was present in letterwriting theory. First, the collection of conversational letters written as models by German professor Christian Fürchtegott Gellert was translated (1774). Then Szymański, a former Jesuit who after papal suppression of the Society became one of the very first modern Polish intellectuals, published Wzory biletów... Trying to make a living by selling his work on the market, he targeted the widest possible audience. He addresses people of all classes, promises practical help, underlines the accessibility of his work and explains things that could be incomprehensible for an uneducated reader (for instance mythological references). He appeals: 
People! Your letters have to reflect an image of your relationship: just as descent, the degree of friendship and other bounds which mutually connect you govern your souls, so they guide the pen. Write whatever you think, and write as if you were speaking. ${ }^{35}$

The most radical advocate of the 'tone of nature' among Polish authors frequently underlines that no one can give specific rules. He encourages readers to treat his models and examples as inspiration and claims that simplicity and naturalness are all that letter-writers need.

Characteristically, Szymański unconditionally equates naturalness with friendly talk-unlike Rousseau he does not even consider that it could be superficial. As the art of salon conversation was not widely cultivated in Poland, in the local context the revolutionary approach principally had to challenge rhetorical tradition that still influenced most educated people very deeply. Szymański does not reject it totally, but repeatedly criticises formulas, pompous panegyrics, exaggerated humility and composing a letter in the same manner as a rhetorical speech. For example, he claims:

All these endless expressions at the end of a letter, 'excuses for boldness', declarations of 'the deepest humility, obeisance and dependence', so numerous that it is hardly possible, and with great labour, to excavate the content of the letter from under a pile of such drivel! Is this the tone of nature? Is this the voice of the heart and the soul? ${ }^{36}$

In the approach founded on sincerity, formulas are seen as a kind of ornament hiding the 'real' content of a letter, which should refer to the writer's particular situation, their 'true' subjective states, emotions, intentions. Moreover-as could be seen above-Szymański presents his theory in conversational style, establishing a pattern of writing in which utterances are to be read as expression of the author's thoughts and emotions.

Nevertheless, although Szymański treats all letter-writing conventions with suspicion, he agrees that the individual should adapt to established custom to some extent. Such an attitude indicates that there is an intrinsic tension between the 'real' emotional subjective state and the social rules which put constraints on expression. Paradoxically, the models and examples provided by Szymański are much more conservative than his theory. Though less pompous and formulaic, the bulk of them still follow the rhetorical patterns of influencing others rather than trying to captivate readers through openness. The underlying opposition between custom and 'true' emotion becomes conventional in itself when in every model of the greeting, the letter-writers claim to write because of their 
'true feelings', not 'mere convention'. Still, some examples of the new approach toward emotional life might be found.

For instance, a letter entitled 'A brother to brother on their father's death' starts with a detailed and dynamic description of the deteriorating condition of a parent. Next, the writer notices:

I am aware, dear Brother, how sensitive and difficult to endure all these descriptions are to a sensible heart; but to no avail! We have to learn that our cries and grief cannot redeem the unpayable debt of mortality. He is our father! It is impossible not to feel pain. He is a human being! One needs to calm down...

Try, Wmć Pan, to deal with your business as soon as you can and come to us! Oh, by God! At this very moment, Marysia informed me that he has $\operatorname{died...37}$

Although the writer refers to the traditional topos of accepting the imminent mortal fate, he does not use a rhetoric formula. The letter does not simply inform of the death, it describes the whole situation, creating the illusion that the writer and the distant addressee are experiencing it emotionally together at the same time. The composition of the letter implies that the rhetorical scheme of consolation is not enough to soothe the pain of the 'sensible heart'. Instead of following this pattern, the writer first tries to create a shared emotional space for compassion and suffering, but then he leaves the addressee alone with the fatal news. This suggests that grief is so strong an emotion that it cannot be fully expressed according to established rules. Such an approach implies that an individual's subjective sphere is seen as something which exceeds the religious and social order.

Nevertheless, the adoption of sincerity as a communicational assumption generates a paradox: how can it be reconciled with decency? Szymański tries to avoid the problem by providing contradictory advice: he suggests writing whatever one is thinking, but recommends caution because a piece of writing cannot be taken back; he advocates showing emotion spontaneously, but calls for delicacy and good taste; he underlines that emotional expression cannot be limited by social convention, but like every sentimentalist he disapproves of feelings directed against others such as anger, contempt, disdain etc.

Such a strategy reflects the mechanism intrinsic to sentimental culture, which was based on the premise that man is naturally good, evil stems from corrupted civilisation and absolute harmony between the independent self and society may be reached when the two are anchored in nature. This notion of naturalness helped to hide social constraints imposed on 
the individual: the strict rules of social convention were replaced by an inner sense. While sentimentalists struggled against 'artificial' and 'corrupted' norms of aristocratic society, they could not fight 'natural' good taste or 'natural' delicacy located within the self. This ambivalence is present in letter-writing manuals from the end of the eighteenth and the early nineteenth century-such as the publications of Filip Neriusz Golański (1788), Antoni Kotschula (1822) and Michał Korzeniowski (1835). ${ }^{38}$ Their authors follow the path proposed by Szymański, but do not advocate for self-expression so boldly. Korzeniowski in particular openly advises social conformity:

Living in the world one has to adjust to its customs and despite various philosophical notes, despite grumbling about superficial politeness and so-called politeness, which stemmed from despicable flattery, ignoble submission to pride etc., if we cannot change it, it is proper to maintain everything that is thought to be decent in the appearance of the letters. ${ }^{39}$

While in the ritual mode following convention was obvious and morally neutral, authors adopting sincerity as their communicational assumption had to mask the discrepancy between the morally-acclaimed postulate of self-expression and the reality of power relations. Indeed, half a century after Szymański's optimistic programme, in the prime of Polish Romanticism Korzeniowski formulated a very defensive theory. His middle-class common sense uncovered the tensions that romantic literature and philosophy tried to hide.

These tensions are clearly reflected in real-life correspondence between Słowacki and his mother (mentioned at the beginning of this article), or letters and doctrine of the Philomats, a secret student society existing between 1817-1823, in which Adam Mickiewicz, future Romantic Bard, played a crucial role. In fact, although these young poets and intellectuals belonged to the noble class, most of them had to struggle to provide for themselves. They followed social trajectories of the Western middle classes, asserting their self-esteem not through money or the birth, but through artistic creativity, patriotism and deep emotions. ${ }^{40}$ They were influenced by sentimental letter-writing manuals and novels, and had to deal with the inescapable tension between the search for truth about oneself, expressing it freely, and following social convention.

Thus the emotionality of the young Polish romantics might be much more deeply rooted in sentimentalism than Polish scholars wish to assert. ${ }^{41}$ Suffice to mention that in the early 1830 s, while living in Geneva, Słowacki had illustrations from Rousseau's Julie... hanging in his room. 


\section{CONCLUSION}

The presented paper aims to conceptualise two notions of communication in the eighteenth century and reveal the two different approaches towards the self, social rules and language that they generate: ritual and sincerity-based. By analysing Rousseau's meta-reflections on communication and Polish letter-writing manuals in wider socio-cultural contexts, I tried to describe the long-term process characteristic of European culture upon entrance to modernity, while asserting the specific character of the Polish context and indicating particularities in its local dynamics. Emphasizing the shift from orality to literacy, decline of rhetorical thinking and development of the discourse of modern prose allowed me to go beyond the history of ideas and identify the change within cultural categories underpinning language practices.

It may be argued that modern sincerity is not only an acclaimed moral virtue or a communicational style: the occurrence of interdependent changes in the notions of communication and the self seems to have been one of the cornerstones of the modern order. The presented analysis shows that not only the concept of the self, but also the concept of communication is culturally constructed and should be closely examined.

\section{WORKS CITED}

Abrams, Meyer H. The Mirror and the Lamp: Romantic Theory and The Critical Tradition. London: Oxford University Press, 1953.

Baczko, Bronisław. Rousseau: samotność i wspólnota. Warszawa: Państwowe Wydawnictwa Naukowe, 1964.

Boczyłowic, Jakub. Wymowny polityk w listach różnych z responsami, w dyskursach politycznych, w weselnych i pogrzebowych mowach etc. etc. Toruń: Jan Chr. Laurer, 1694.

Bohomolec, Franciszek. Zabawki oratorskie niektórych kawalerów. Warszawa, 1755.

Brant, Claire. Eighteenth-Century Letters and British Culture. Basingstoke: Palgrave Macmillan, 2010.

Bystrzonowski, Wojciech. Polak sensat w liście, w komplemencie polityk, humanista w dyskursie, w mowach statysta, na przyktad dany szkolnej młodzi. Lublin: Drukarnia Kolegium Societatis Jesu, 1730.

Campbell, Colin. The Romantic Ethic and the Spirit of Modern Consumerism. Oxford: Basil Blackwell, 1994.

Craveri, Benedetta. The Age of Conversation. Trans. Teresa Waugh. New York: New York Review Books, 2005.

Csengei, Ildiko. 'I Will Not Weep: Reading through the Tears of Henry Mackenzie's Man of Feeling.' The Modern Language Review 103:4 (Oct, 2008) 952-968, DOI: https://doi. org/10.2307/20468024.

Dietzsch, Steffen. Krótka historia ktamstwa. Trans. Krystyna Krzemieniowa. Warszawa: Muza, 2000. 
Dziechcińska, Hanna. Świat i cztowiek w pamiętnikach trzech stuleci: XVI-XVII-XVIII w. Warszawa: Instytut Badań Literackich (Polska Akademia Nauk), 2003.

Elias, Norbert. On the Process of Civilisation: Sociogenetic and Psychogenetic Investigations. Trans. Edmund Jephcott. In: Stephen Mennell, Eric Dunning, Johan Goudsblom and Richard Kilminster (eds.). Dublin: UCD Press, 2012.

Idem. Studies on the Germans: Power Struggles and the Development of Habitus in the Nineteenth and Twentieth Centuries. Trans. Eric Dunning and Stephen Mennell. In: Stephen Mennell and Eric Dunning (eds.). Dublin: UCD Press, 2013.

Golański, Filip Neriusz. Listy, memoriaty $i$ supliki z uwagami stosownymi przez autora 'O wymowie $i$ poezji.' Wilno: Drukarnia Jego Królewskiej Mości, 1788.

Goodman, Dena. The Republic of Letters: A Cultural History of the French Enlightenment. Ithaca: Cornell University Press, 1994.

Guignon, Charles. On Being Authentic. London-New York: Routledge, 2004.

Guilhamet, Leon. The Sincere Ideal: Studies on Sincerity in Eighteenth-Century English Literature. Montreal: McGill-Queen's University Press, 1974.

Havelock, Erick. Preface to Plato. Cambridge: Harvard University Press, 1963.

Jurkowska, Hanna. Pamięć sentymentalna. Warszawa: Wydawnictwa Uniwersytetu Warszawskiego, 2014.

Korzeniowski, Michał. Sekretarz doskonaty. Książka podręczna zawierająca wybór wzorowych listów we wszystkich stosunkach $i$ okolicznościach potocznego życia, wybranych z dziet Krasickiego, Kotschuli, Królikowskiego, Rumsa i wielu innych; wzory listów kupieckich, krótkie objaśnienie i wzory wekslów, obligów itp; wzory przedstawień do wtadz, wzory kontraktów, testamentów, rozmaitych zapisów, zaświadczeń i innych aktów urzędowych. Wrocław: Zygmunt Schletter, 1835.

Kotschula, Antoni. Wzór listów w rozmaitych okolicznościach życia towarzyskiego pisanych dla użytku sprawujących interesa i uczacych się sztuki pisania listów. Wrocław: Wilhelm Bogumił Korn, 1822.

Lejeune, Philippe. 'La révolution autobiographique.' In idem Signes de vie. Le Pacte autobiographique 2. Paris: Seuil, 2005, 209-2014.

Martin, John. 'Inventing Sincerity, Refashioning Prudence: The Discovery of the Individual in Renaissance Europe.' American Historical Review 102:5 (Dec, 1997) 1309-1342, URL: http://www.jstor.org/stable/2171065.

Melzer, Arthur. 'Rousseau and the Modern Cult of Sincerity.' The Harvard Review of Philosophy 5:1 (1995) 4-21. 10.5840/harvardreview1995511.

Mencwel, Andrzej. Łacznik: Ziemiańska wtórna oralność. In idem, Wyobraźnia antropologiczna. Próby i studia. Warszawa: Wydawnictwa Uniwersytetu Warszawskiego, 2006.

Olson, David R. The World on Paper: The Conceptual and Cognitive Implications of Writing and Reading. Cambridge: Cambridge University Press, 1994.

Ong, Walter J. Rhetoric, Romance and Technology. Studies in the Interaction of Expression and Culture. Ithaca, NY: Cornell University Press, 1971.

Idem. Orality and Literacy: The Technologizing of the Word. London-New York: Methuen, 1982.

Ostrowski-Danejkowicz, Jan. Swada polska i tacińska albo miscellanea oratorskie, sejmowe, weselne, kancelaryjne, kaznodziejskie, elogjarne, inskrypcyjne i inne różne, w oboim języku prozą $i$ wierszem. Lublin: Drukarnia Jego Królewskiej Mości Collegium Societatis Jesu, 1745.

Reddy, William M. The Navigation of Feeling: A Framework for the History of Emotions. Cambridge: Cambridge University Press, 2001.

Rousseau, Jean Jacques. Confessions. Trans. Scholar Angela. Oxford: Oxford University Press, 2000.

Idem. Julie, Or the New Heloise: Letters of Two Lovers Who Live in a Small Town at the Foot of the Alps. In: Philip Stewart and Jean Vaché (Trans. and eds.). Hanover, NH: Dartmouth College and University Press of New England, 1997.

Seligman, Adam B., Robert P. Weller, Michael J. Puett and Bennett Simon. Ritual and Its Consequences: An Essay on the Limits of Sincerity. New York: Oxford University Press, 2008. 
Sennett, Richard. The Fall of Public Man. New York: W.W. Norton, 1992.

Sikora, Agata. Szczerość. O wytanianiu się porządku nowoczesnego. Warszawa: Wydawnictwa Uniwersytetu Warszawskiego, in print.

Słowacki, Juliusz. Korespondencja Juliusza Stowackiego. In: Eugeniusz Sawrymowicz (ed.). Wrocław-Warszawa-Kraków: Ossolineum, 1962.

Starobinski Jean. Jean-Jacques Rousseau: Transparency and Obstruction. Trans. Arthur Goldhammer, intro. Robert J. Morrissey. Chicago: University of Chicago Press, 1988.

Stewart Louisa to Walter Scott, 4 September 1826. In: Wilfred Partington (ed.), The Private Letter-Books of Sir Walter Scott. London: Hodder and Stoughton, 1930, 273 quoted in: Csengei 2008.

Szymański, Stanisław. Wzory biletów, listów $i$ memoriałów w różnych materiach z przydatkiem uwag powszechnych o stylu listownym, przypisków względem szczególnych listów gatunków i drobnych przestróg względem formalności w pisaniu. v. 1, Warszawa: Drukarnia Nadworna Jego Królewskiej Mości, 1784; v. 2, Warszawa: Drukarnia Pojezuicka, 1795.

Taylor, Charles. Sources of the Self: The Making of the Modern Identity. Cambridge: Harvard University Press, 1989.

Idem. The Ethics of Authenticity. Cambridge: Harvard University Press, 1995.

Ernst van Alphen, Mieke Bal and Carel Smith (eds.). The Rhetoric of Sincerity. Stanford: Stanford University Press, 2009.

Trilling, Lionel. Sincerity and Authenticity. London: Oxford University Press, 1972.

Warchala, Michał. Autentyczność i nowoczesność. Idea autentyczności od Rousseau do Freuda. Kraków: Universitas, 2006.

Wieruszewski, Kazimierz. Fama polska publiczne stany i mtódź szlachetna informująca. Poznań: Drukarnia Kollegium Soc. Jesu, 1720.

Witkowska, Alina. Rówieśnicy Mickiewicza. Życiorys jednego pokolenia. Warszawa: Instytut Badań Literackich (Polska Akademia Nauk), Oficyna Wydawnicza Rytm, 1998.

Zajączkowski, Andrzej. Szlachta polska. Kultura i struktura. Warszawa: Semper, 1993.

Zatorski, Aleksander Paweł. Przydatek do uwag zupetnemu stanowiacych się szcześsiu, stużących etc. osobliwy, przez tegoż, co i przed tym Podgórzanina, Ich Mciów kawalerów ciekawości i pożytkowi poświęcony, to jest listów rozlicznych do delikatnej o pozwolona przyjaźń negocjacji stużących, tomików dwa. v. 1, Kraków 1746 [1747]. V. 2, Wrocław: 1746 [1747].

\section{ABOUT THE AUTHOR}

Agata Sikora, PhD. She is an independent scholar and Polish cultural journalist based in London. A winner of a doctoral scholarship funded by National Science Centre (Poland), she completed her doctoral thesis at the University of Warsaw (Institute of Polish Culture), took part in a doctoral Erasmus exchange at the University of Amsterdam, paid a research visit at Queen Mary University of London (The Centre for History of Emotions). She has published the book Wolność, równość, przemoc. Czego nie chcemy sobie powiedzieć [Freedom, Equality, Power. What We Don't Want to Tell to Each Other] (Wydawnictwo Karakter 2019), which was nominated for the Gdynia Literary Prize, and contributed to numerous Polish academic journals and collective volumes. Her book 'Szczerość. O wyłanianiu się nowoczesnego porządku komunikacyjnego' [Sincerity. On the Emergence of the Modern Communicational Regime] based on her PhD thesis will be published soon (Wydawnictwa Uniwersytetu Warszawskiego). E-mail: agata.anna.sikora@gmail.com. 


\section{NOTES}

1 This article is based on my PhD dissertation, to be published as a book: Szczeraść. O wytanianiu się porzadku nowoczesnego. Warszawa: Wydawnictwa Uniwersytetu Warszawskiego. I received funding for my PhD from the scholarship programme 'Etiuda' by the National Science Centre (Poland) on the basis of decision no. UMO-2013/08/T/ HS2/00351.

2 Słowacki Juliusz to Salomea Bécu, April 1832. In: Słowacki, Juliusz and Eugeniusz Sawrymowicz (eds.), Korespondencja Juliusza Stowackiego. Wrocław-Warszawa-Kraków: Ossolineum, 1962, v. 1, (107).

3 Dietzsch, Steffen. Krótka historia ktamstwa. Trans. Krystyna Krzemieniowa, Warszawa: Muza, 2000 (26).

4 Martin, John. 'Inventing Sincerity, Refashioning Prudence: The Discovery of the Individual in Renaissance Europe.' American Historical Review 102:5 (Dec, 1997) 1309-1342. URL: http://www.jstor.org/stable/2171065.

5 Trilling, Lionel. Sincerity and Authenticity. London: Oxford University Press, 1972; Guilhamet, Leon. The Sincere Ideal: Studies on Sincerity in Eighteenth-Century English Literature. Montreal: McGill-Queen's University Press, 1974.

6 Campbell, Colin. The Romantic Ethic and the Spirit of Modern Consumerism. Oxford: Basil Blackwell, 1994 (esp. 99-160).

7 Campbell 1994. Elias, Norbert, Studies on the Germans: Power Struggles and the Development of Habitus in the Nineteenth and Twentieth Centuries. Trans. Eric Dunning, Stephen Mennell. In: Stephen Mennell and Eric Dunning (eds.). Dublin: UCD Press, 2013. Idem. On the Process of Civilisation: Sociogenetic and Psychogenetic Investigations. Trans. Edmund Jephcott. In: Stephen Mennell, Eric Dunning, Johan Goudsblom and Richard Kilminster (eds.). Dublin: UCD Press, 2012.

8 Stewart Louisa to Walter Scott, 4 September 1826. In: Wilfred Partington (ed.), The Private Letter-Books of Sir Walter Scott. London: Hodder and Stoughton, 1930, 273. Cited in: Csengei, Ildiko. 'I will not weep: Reading through the tears of Henry Mackenzie's Man of feeling.' The Modern Language Review 103:4 (2008) 952-968, DOI: https://doi. org/10.2307/20468024.

9 Reddy, William M. The Navigation of Feeling: A Framework for the History of Emotions. Cambridge: Cambridge University Press, 2001. Melzer, Arthur. 'Rousseau and the Modern Cult of Sincerity.' The Harvard Review of Philosophy 5:1 (1995) 4-21, 10.5840/harvardreview1995511. Sennett, Richard. The Fall of Public Man. New York: W.W. Norton, 1992. Taylor, Charles. Sources of the Self: The Making of the Modern Identity. Cambridge: Harvard University Press, 1989. Idem. The Ethics of Authenticity. Cambridge: Harvard University Press, 1995. Seligman, Adam B., et al. Ritual and Its Consequences: An Essay on the Limits of Sincerity. New York: Oxford University Press, 2008.

10 Lejeune, Philippe. 'La révolution autobiographique.' In idem Signes de vie. Le Pacte autobiographique 2. Paris: Seuil, 2005, 209-2014. Melzer 1995 (7). Taylor 1995. Guignon, Charles. On Being Authentic. London-New York: Routlege, 2004 (55). Baczko, Bronisław. Rousseau: samotność $i$ wspólnota. Warszawa: Państwowe Wydawnictwa Naukowe, 1964 (11). Warchala, Michał. Autentyczność i nowoczesność. Idea autentyczności od Rousseau do Freuda. Kraków: Universitas, 2006, chapter 1 (35-78).

11 Ong, Walter J. Rhetoric, Romance and Technology. Studies in the Interaction of Expression and Culture. Ithaca, NY: Cornell University Press, 1971. Idem. Orality and Literacy: The Technologizing of the Word. London-New York: Methuen, 1982.

12 Sennett 1992. Goodman, Dena. The Republic of Letters: A Cultural History of the French Enlightenment. Ithaca: Cornell University Press, 1994. Craveri, Benedetta. The Age of Conver- 
sation. Trans. Teresa Waugh. New York: New York Review Books, 2005. Abrams, Meyer H. The Mirror and the Lamp: Romantic Theory and The Critical Tradition. London: Oxford University Press, 1953.

13 Seligman 2008 (21-28).

14 Rousseau, Jean-Jacques. Julie, Or the New Heloise: Letters of Two Lovers Who Live in a Small Town at the Foot of the Alps. Trans. and ed. Philip Stewart, Jean Vaché. Hanover, NH: Dartmouth College and University Press of New England, 1997 (190).

15 Idem (10).

16 Ibidem.

17 Rousseau, Jean-Jacques. Confessions. Trans. Angela Scholar. Oxford: Oxford University Press, 2000 (5).

18 Many scholars underline this fundamental paradox of sincerity: although it should be absolutely transparent, in practice, among people it needs to be problematised. When problematised, it undermines itself. Seligman, Adam B., et al. 2008. Ernst van Alphen, Mieke Bal and Carel Smith (eds.), The Rhetoric of Sincerity, Stanford: Stanford University Press, 2009.

19 Rousseau 2000 (170).

20 Ong 1971. Ong 1982.

21 Olson, David R. The World on Paper: The Conceptual and Cognitive Implications of Writing and Reading. Cambridge: Cambridge University Press, 1994.

22 Zajączkowski, Andrzej. Szlachta polska. Kultura i struktura. Warszawa: Semper, 1993 (70).

23 Ong 1982. Havelock, Erick. Preface to Plato. Cambridge: Harvard University Press, 1963. Mencwel, Andrzej, Łącznik: Ziemiańska wtórna oralność. In idem, Wyobraźnia antropologiczna. Próby i studia. Warszawa: Wydawnictwa Uniwersytetu Warszawskiego, 2006, (99-106).

24 I treat these publications as a meta-reflection on communication, not a direct reflection of actual practices. On the relationship between manuals and letter-writing practice see: Brant, Claire. Eighteenth-Century Letters and British Culture. Basingstoke: Palgrave Macmillan, 2010 (39).

25 I have modernised spelling, punctuation and capitalisation of titles and quotations.

26 Fama... is an exception: it contains only letters.

27 WMM Pan is a way of addressing male nobles.

28 Boczyłowic, Jakub. Wymowny polityk w listach różnych z responsami, w dyskursach politycznych, w weselnych $i$ pogrzebowych mowach etc. etc. Torun: Jan Chr. Laurer, 1694 (24-25). The letters do not only include Latin words, they also follow the patterns of Latin syntax to a large extent. I simplify the most complicated inversions in the provided translation.

29 William Reddy calls such expressions 'emotives' and underlines that they cannot be interpreted as descriptives because they influence others as part of the social script of behaviour and at the same time they elucidate or change the emotional state of an individual. Reddy 2001.

30 Boczyłowic 1694 (25).

31 Bystrzonowski, Wojciech. Polak sensat w liście, w komplemencie polityk, humanista w dyskursie, w mowach statysta, na przyktad dany szkolnej młodzi. Lublin: Drukarnia Kolegium Societatis Jesu, 1730. The publication lacks page numbering.

32 Zatorski, Aleksander Paweł. Przydatek do uwag zupetnemu stanowiących się szczęściu, stużących etc. osobliwy, przez tegoż, co i przed tym Podgórzanina, Ich Mciów kawalerów ciekawości i pożytkowi poświęcony, to jest listów rozlicznych do delikatnej o pozwolona przyjaźn negocjacji stużących, tomików dwa. v. 1, Kraków 1746 [1747]. V. 2, Wrocław: 1746 [1747].

33 Dziechcińska, Hanna. Świat $i$ cztowiek w pamiętnikach trzech stuleci: XVI-XVII-XVIII w. Warszawa: Instytut Badań Literackich (Polska Akademia Nauk), 2003.

34 Jurkowska, Hanna. Pamięć sentymentalna. Warszawa: Wydawnictwa Uniwersytetu Warszawskiego, 2014. 
35 Szymański, Stanisław. Wzory biletów, listów i memoriatów, w różnych materiach..., v. 1, Warszawa: Drukarnia Nadworna Jego Królewskiej Mości, 1784 (2-3).

36 Idem (23).

37 Idem (269-270).

38 Golański, Filip Neriusz. Listy, memoriaty $i$ supliki z uwagami stosownymi przez autora ' $O$ wymowie i poezji.' Wilno: Drukarnia Jego Królewskiej Mości, 1788. Kotschula, Antoni, Wzór listów w rozmaitych okolicznościach życia towarzyskiego pisanych dla użytku sprawujących interesa $i$ uczacych się sztuki pisania listów. Wrocław: Wilhelm Bogumił Korn, 1822. Korzeniowski, Michał. Sekretarz doskonaty. Książka podręczna zawierająca wybór wzorowych listów we wszystkich stosunkach i okolicznościach potocznego życia, wybranych z dziet Krasickiego, Kotschuli, Królikowskiego, Rumsa i wielu innych; wzory listów kupieckich, krótkie objaśnienie i wzory wekslów, obligów itp.; wzory przedstawień do władz, wzory kontraktów, testamentów, rozmaitych zapisów, zaświadczén i innych aktów urzędowych. Wrocław: Zygmunt Schletter, 1835.

39 Korzeniowski 1835 (6).

40 Witkowska, Alina. Rówieśnicy Mickiewicza. Życiorys jednego pokolenia, Warszawa: Instytut Badań Literackich (Polska Akademia Nauk); Oficyna Wydawnicza Rytm, 1998.

41 I discuss this in more detail in: Sikora, Agata. Szczerość. O wytanianiu się nowoczesnego porzadku. Warszawa: Wydawnictwa Uniwersytetu Warszawskiego, In print, part II, chapters 3 and 4 (302-428, esp. 368). 